\title{
EFFECT OF BURNISHING ON THE CONTACT FATIGUE OF REGENERATIVE THERMALLY SPRAYED COATINGS
}

\author{
Robert Starosta \\ Gdynia Maritime University, Department of Marine Maintenance \\ Morska Street 81-87, 81-225 Gdynia, Poland \\ tel.: +48 586901249 , fax: +48586901399 \\ e-mail: starosta@am.gdynia.pl
}

\begin{abstract}
This study of the resistance to contact fatigue of $\mathrm{Ni}-5 \% \mathrm{Al}$ alloy coatings and $\mathrm{Ni}-5 \% \mathrm{Al}-15 \% \mathrm{Al}_{2} \mathrm{O}_{3}$ composite coatings were evaluated. The coatings were prepared by flame spraying (Casto-Dyn DS 8000 torch) and plasma spraying (PN 120 plasma jet). The coatings were subjected to a finishing treatment: turning, burnishing and grinding. Depending on coatings phase composition and finishing treatment, the parameter mean values of surface roughness (Ra) were in the wide range of 0.28 to $2.61 \mu \mathrm{m}$. The coatings after burnishing characterized by smallest of surface roughness. The largest value of the parameter Ra was observed in the case of coatings after turning. The presence of the reinforcing phase in the coating increases the surface roughness of thermally sprayed composite coatings. The hardness of coatings also depends on the finishing methods. The minimum hardness equal to 192 HV2 was found in the case of coatings of $\mathrm{Ni}-5 \% \mathrm{Al}$ obtained by using a Casto-Dyn DS 8000 gas torch. Burnished $\mathrm{Ni}-5 \% \mathrm{Al}_{-}-15 \% \mathrm{Al}_{2} \mathrm{O}_{3}$ coatings obtained by plasma spraying characterized by hardness 291 HV2.

Resistance of fatigue surface of thermally sprayed coatings on a SCF (standing contact fatigue) test stand was assessed. The test was designed based on the guidelines of the PN-80/H-04324 Polish standard. During the fatigue tests were provided constant contact of co-acting parts, without slipping.

Based on the survey it was found that the plasma sprayed coatings (PN120 plasma-jet) have a greater resistance to fatigue then the coatings obtained by flame spraying Casto-Dyn DS 8000 torch. Composite coatings of Ni-5\%Al$15 \% \mathrm{Al}_{2} \mathrm{O}_{3}$ are more resistant to contact fatigue, compared to the alloy coatings of $\mathrm{Ni}-5 \% \mathrm{Al}$. Burnishing increases the fatigue resistance of coatings when compared to turning. Burnished and polished surfaces are characterized by a similar contact fatigue resistance.
\end{abstract}

Keywords: thermal spraying, $\mathrm{Ni}-5 \% \mathrm{Al}-\mathrm{Al}_{2} \mathrm{O}_{3}$ coatings, contact fatigue

\section{Introduction}

The fatigue is one of the exploitation properties of the object, which change preferably by burnishing treatment $[7,10]$. Fatigue cracks usually formed on the surface. Therefore, the state of the surface (geometric structure, microstructure, hardness, stress) can have a significant effect on the fatigue strength [11]. The most fatigue strength depends on the surface roughness. The cavities of surface roughness formed structural notches which reducing of fatigue strength. Reducing the surface roughness from $\mathrm{Ra}=2.5 \mu \mathrm{m}$ to $\mathrm{Ra}=0.16 \mu \mathrm{m}$ can several dozen per cent of improve the fatigue strength $[1,5]$. The surface roughness is smaller, the smaller is the number of geometric and structural micro-notches. It arises from worse conditions for the initiation of fatigue microcracks [7].

Plastic strain of materials cause hardening of the material grains of the surface layer in a positive effect on the fatigue strength. As a result of increased dislocation density and formation of compressive residual stresses and surface layer hardening the increase of fatigue strength was observed. For example, after burnishing appear a rise of $25-90 \%$ fatigue strength $[1,10,11]$.

Stresses play a fundamental role in the process of the fatigue fracture in the surface layer. Compressive internal stresses cause an increase in fatigue strength, and tensile stresses opposite reduce it. Therefore often the effect of different surface treatments on the material resistance to fatigue cracking can be seen by analyzing the state of stresses in the surface layer $[1,10,11]$. 
In the case of machining the type of stress is largely dependent on the temperature of the surface. The processing generates more heat, the higher the tensile stresses occur in the surface layer. Burnishing provides the creation of a surface layer of high compressive stress. Therefore very often it can by observed increase fatigue resistance (contact and volume) of the burnished material $[2,4,6,8,9$, ].

Assessed coatings to will used for the regeneration of shafts of marine centrifugal pumps.

\section{Preparation of pivots for burnishing}

The coatings were sprayed on steel shafts pivots (X5CrNi 18-10) with diameter $\phi=40 \mathrm{~mm}$. To increase the adhesion of the coatings, the pivots were threaded. For spraying a PN 120 plasma-jet and Casto-Dyn DS 8000 gas torch were used. Two kind of material powders were used, a) ProXon 21021 (Ni- 93.45\%, Al-5\%, B-0.8\%, Fe-0.34\%, Cr-0.18\%, Si-0.15\%, C-0.08\%) and b) MetaCeram $28020\left(\mathrm{Al}_{2} \mathrm{O}_{3}-97,7 \%, \mathrm{TiO}_{2}-2,2 \%, \mathrm{SiO}_{2}-0,1 \%\right)$. The powders made by Castolin. The $15 \%$ volume fraction of powder MetaCeram 28020 in composite coating material was used

The following parameters of plasma spraying have been applied:

- argon pressure: 0,35 $\mathrm{MPa}$,

- the distance of the nozzle from the surface : 70-100 mm,

- current: 450-600 A,

- voltage arc internal: 47-60V.

The following parameters of flame spraying have been applied:

- acetylene pressure: $0.07 \mathrm{MPa}$,

- oxygen pressure: $0.4 \mathrm{MPa}$,

- air pressure: $0.1 \mathrm{MPa}$,

- spraying speed: $25 \mathrm{~m} / \mathrm{min}$,

- feed: $3 \mathrm{~mm} / \mathrm{rev}$,

- burner distance from the sprayed surface: $150 \mathrm{~mm}$,

- number of applied layers: 6, coatings thickness were 1-1.2 mm.

Spraying coatings were obtained on pre-heated steel substrate to a temperature of $60{ }^{\circ} \mathrm{C}$. Then, it was sprayed coating process with a so that the temperature of the shell shall not exceed $80^{\circ}$. In the case of the first layer of composite coating was applied without phase dispersion, in order to improve adhesion of coatings to the steel substrate.

After spraying, the coating was subjected to initial treatment in order to obtain the required dimensions and reduce of deviations shape (roundness and cylindricity) of the pivots shafts. Three types of finishing treatments and turning, burnishing and grinding was used.

$\mathrm{Ni}-5 \% \mathrm{Al}$ alloy and $\mathrm{Ni}-5 \% \mathrm{Al}-15 \% \mathrm{Al}_{2} \mathrm{O}_{3}$ composite coatings were machining by means of trigon inserts. Its catalogue number is GC 3210 (Sandvig Coromant) . GC 3210 is a material based on tungsten carbide with a supplement of titanium nitride, covered with a TiN coating obtained by CVD method. In the DWLNRL-2525M08 holder a WMNG 080408-KM insert was mounted. Insert and the holder was manufactured by Sandvik Coromant. The geometry of the cutting tool, takes into account the insert and tool holder are follows:

- cutting inserts angle $-\beta=80^{\circ}$,

- approach angle $-\kappa_{\mathrm{r}}=95^{\circ}$,

- rake angle $-\gamma=-6^{\circ}$,

- clearance angle $-\alpha=6^{\circ}$,

- nose radius $-r_{\varepsilon}=0.8 \mathrm{~mm}$.

Turning parameters were used:

- cutting speed $-\mathrm{V}_{\mathrm{c}}=100 \mathrm{~m} / \mathrm{min}$,

- feed rate $-\mathrm{f}=0.06 \mathrm{~mm} / \mathrm{rev}$,

- cutting depth $-\mathrm{ap}_{\mathrm{p}}=0.3 \mathrm{~mm}$. 
After turning, burnishing treatment was performed. The burnishing process was conducted with use one-roller Yamato SRMD burnisher. Burnishing parameters were as follows:

- burnishing force $-\mathrm{F}_{\mathrm{n}}=700 \mathrm{~N}$ (during the processing of composite coatings) and $1100 \mathrm{~N}$ (during the processing of alloy coatings),

- burnishing speed $-\mathrm{v}_{\mathrm{n}}=28 \mathrm{~m} / \mathrm{min}$,

- burnishing feed $-\mathrm{f}_{\mathrm{n}}=0.044 \mathrm{~mm} / \mathrm{rev}$ (during the processing of composite coatings) and 0.08 $\mathrm{mm} / \mathrm{rev}$ (during the processing of alloy coatings).

In the case of flame sprayed coatings obtained by using Casto-Dyn DS 8000 torch also the effect of grinding treatment on contact fatigue was assessed. For the grinding Chris Marine $75 \mathrm{H}$ lathe grinder was used. Grinding treatment according to the manufacturer of the coating material was performed. For treatment of coatings the 01-90x10x32 39C-60-H6V grinding wheel was used. Grinding parameters were as follows:

- wheel feed-in $-\mathrm{a}_{\mathrm{e}}=0.02 \mathrm{~mm}$,

- workpiece peripheral speed $-\mathrm{v}_{\mathrm{p}}=28 \mathrm{~m} / \mathrm{min}$,

- wheel peripheral speed $\mathrm{v}_{\mathrm{s}}=25 \mathrm{~m} / \mathrm{s}$,

- axial feed $\mathrm{f}_{\mathrm{o}}=0.06 \mathrm{~mm} / \mathrm{rev}$.

\section{Methodology of research}

Surface roughness was measured with a profilometer HOMMEL TESTER T1000. The length of the measurement section was $4.8 \mathrm{~mm}$, and the fundamental section was $0.8 \mathrm{~mm}$.

The hardness measurement was performed by means of Vickers method with the use of WPM device, at thrust force amounting to $20 \mathrm{~N}$.

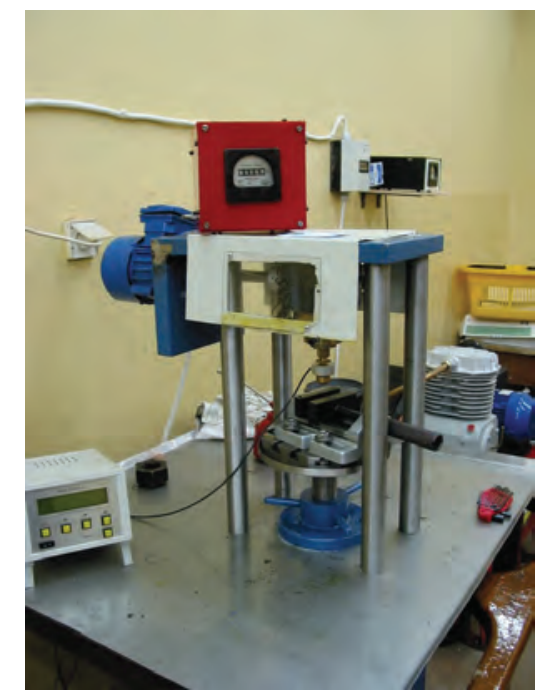

Fig. 1. The test stand for the assessment of standing contact fatigue resistance [2]

The test stand used for the evaluation of fatigue resistance of thermally sprayed coating, after machining, is shown in Fig. 1. The test was designed based on the guidelines of the PN-H04324.1980 Polish standard. During the fatigue tests were provided constant contact of co-acting parts, without slipping. The closed cycle load was used. The value of maximum force Fs was 28 $\mathrm{N}$. The average value of force during the fatigue test equaled $15 \mathrm{~N}$. Recommendation PN-H04324.1980 standards for fatigue testing determine the number of cycles per $N_{G}=2 \cdot 10^{7}$. After tests on the coatings surface was not observed any signs of wear. Therefore, the number of cycles to $\mathrm{N}_{\mathrm{G}}=8.06 \cdot 10^{7}$ were increased. Counter specimen was a ball with a diameter of $10 \mathrm{~mm}$ was made of hardened C45 steel with a hardness of $54 \mathrm{HRC}$. As a criterion for damage of the sample in contact fatigue tests assumed the volume of surface of fatigue wear. 
Size losses fatigue was rated by coatings surface topography performed Hommel-Etamic T8000 profilometer.

\section{Results}

The coatings were subjected to a finishing treatment: turning, burnishing and grinding. Depending on coatings phase composition and finishing treatment, the parameter mean values of surface roughness $(\mathrm{Ra})$ were in the wide range of 0.28 to $2.61 \mu \mathrm{m}$. The $\mathrm{Ni}-5 \% \mathrm{Al}$ coatings after burnishing characterized by smallest of surface roughness. After turning roughness of these coatings was three (for plasma spraying) and nine (for flame spraying) times greater. $\mathrm{Ni}-5 \% \mathrm{Al}$ and $\mathrm{Ni}-5 \% \mathrm{Al}-15 \% \mathrm{Al}_{2} \mathrm{O}_{3}$ coatings roughness after grinding was $\mathrm{Ra}=0.62 \mu \mathrm{m}$ and $\mathrm{Ra}=0.89 \mu \mathrm{m}$. The largest value of the parameter $\mathrm{Ra}$ was observed in the case of composite $\mathrm{Ni}-5 \% \mathrm{Al}-15 \% \mathrm{Al}_{2} \mathrm{O}_{3}$ coatings, obtained by flame spraying, after turning. The presence of the reinforcing phase in the coating increases the surface roughness of thermally sprayed composite coatings. The hardness of coatings also depend on the finishing methods (Fig. 2). The minimum hardness equal to $192 \mathrm{HV} 2$ was found in the case of coatings of Ni-5\% Al obtained by using a Casto-Dyn DS 8000 gas torch. Burnished Ni-5\% Al- $15 \% \mathrm{Al}_{2} \mathrm{O}_{3}$ coatings obtained by plasma spraying characterized by hardness 291 HV2.
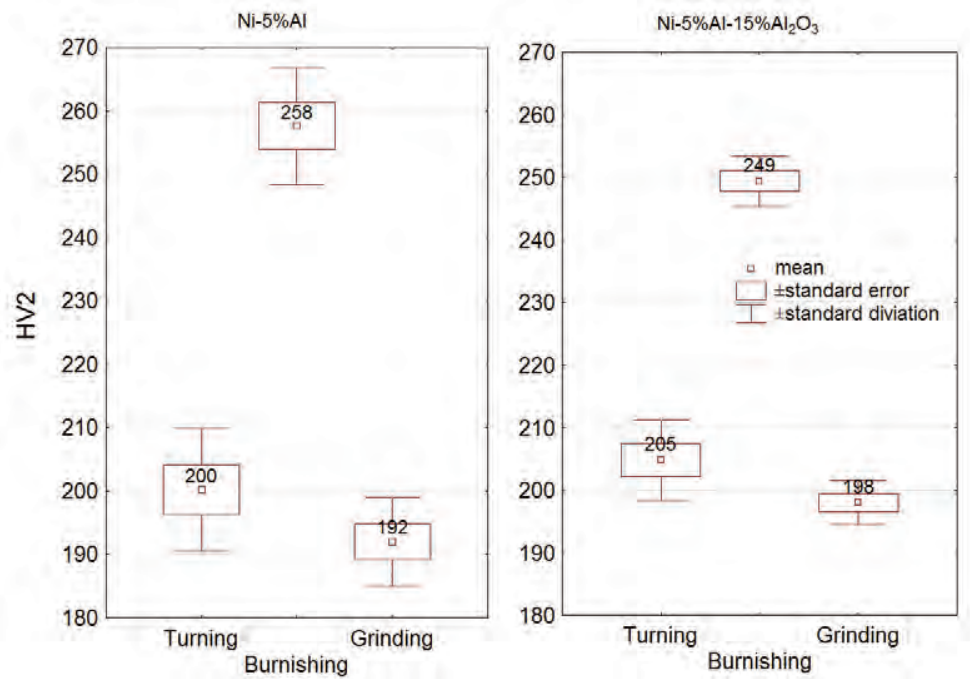

Fig. 2. The hardness of coatings obtained by flame spraying (Casto-Dyn DS 8000 torch)

As a result of the experiment on the surface of the material loss was observed. Examples of a contour map of the samples subjected contact fatigue test are shown in Fig. 3. The Fig. 4 and 5 show examples of 3D topography of the surface coatings after the contact fatigue tests. In Fig. 6 presents examples of unfiltered 2D profiles made in place of the cyclic impact of ball.

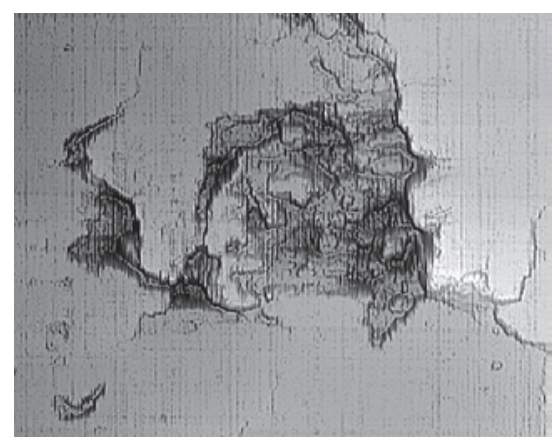

Fig. 3. The surface damage of $\mathrm{Ni}-5 \% \mathrm{Al}-15 \% \mathrm{Al}_{2} \mathrm{O}_{3}$ coating due contact fatigue after burnishing 


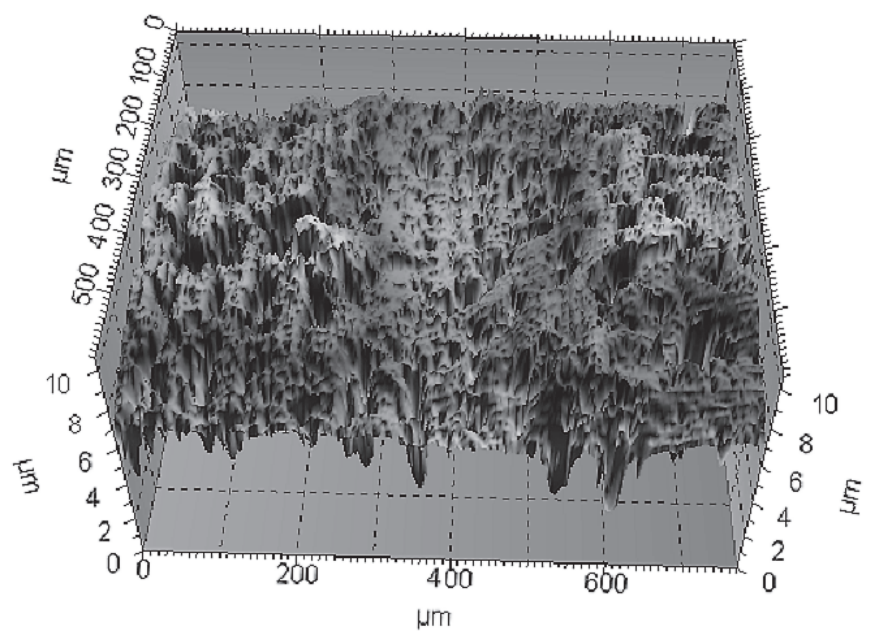

Fig. 4. The topography of burnished surface of plasma sprayed Ni-5\%Al coating with fatigue damage

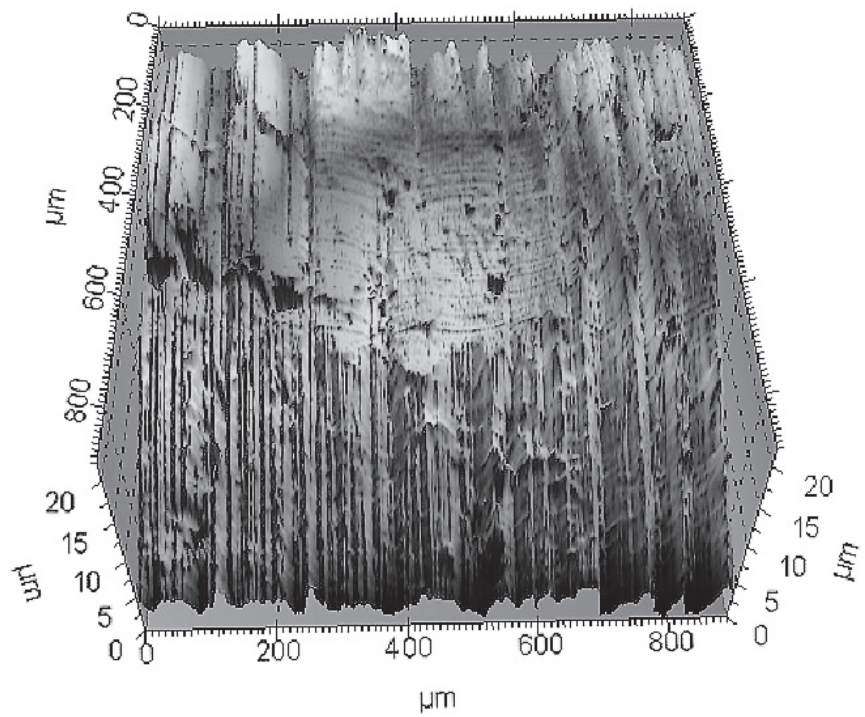

Fig. 5. The topography of grinded surface of flame sprayed Ni-5\%Al coating with fatigue damage

Tab.1. The measurement results of surface area and volume of the coatings material decrements of contact fatigue

\begin{tabular}{|c|c|c|c|}
\hline \multirow[t]{2}{*}{ Coating } & \multirow[t]{2}{*}{ Type of finishing } & \multicolumn{2}{|c|}{ Measurement results of contact fatigue damage } \\
\hline & & The surface area, $\mu \mathrm{m}^{2}$ & Volume, $\mu \mathrm{m}^{3}$ \\
\hline \multicolumn{4}{|c|}{ Flame sprayed coatings - Casto-Dyn DS 8000 torch } \\
\hline \multirow[t]{3}{*}{$\mathrm{Ni}-5 \% \mathrm{Al}$} & turning & 94471 & 79368 \\
\hline & burnishing & 50802 & 68700 \\
\hline & grinding & 49458 & 70377 \\
\hline \multirow{3}{*}{$\begin{array}{l}\mathrm{Ni}-5 \% \mathrm{Al}- \\
15 \% \mathrm{Al}_{2} \mathrm{O}_{3}\end{array}$} & turning & 69401 & 73310 \\
\hline & burnishing & 46602 & 64279 \\
\hline & grinding & 46154 & 68867 \\
\hline \multicolumn{4}{|c|}{ Plasma sprayed coatings - PN 120 plasmatron } \\
\hline \multirow[t]{2}{*}{$\mathrm{Ni}-5 \% \mathrm{Al}$} & turning & 36879 & 18719 \\
\hline & burnishing & 23400 & 11689 \\
\hline \multirow{2}{*}{$\begin{array}{l}\mathrm{Ni}-5 \% \mathrm{Al}- \\
15 \% \mathrm{Al}_{2} \mathrm{O}_{3}\end{array}$} & turning & 25874 & 21054 \\
\hline & burnishing & 9459 & 20377 \\
\hline
\end{tabular}


a)

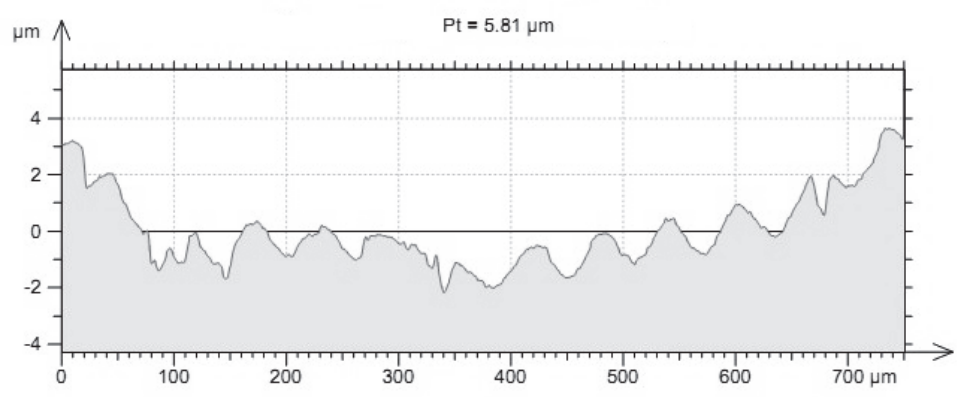

b)

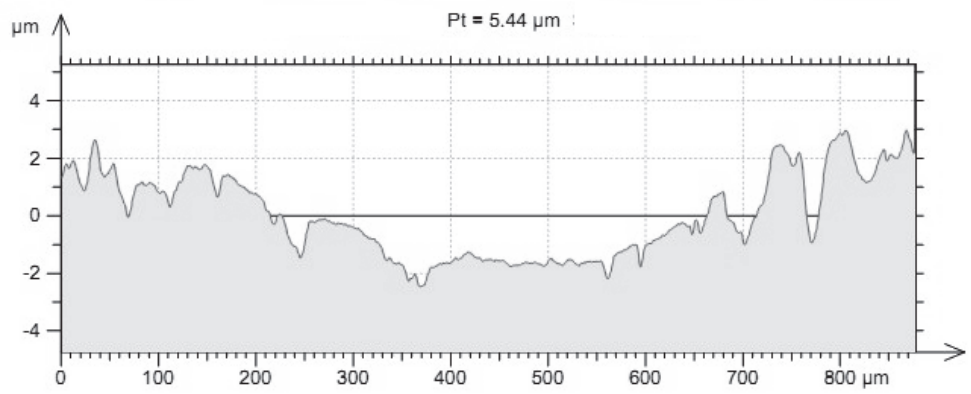

c)

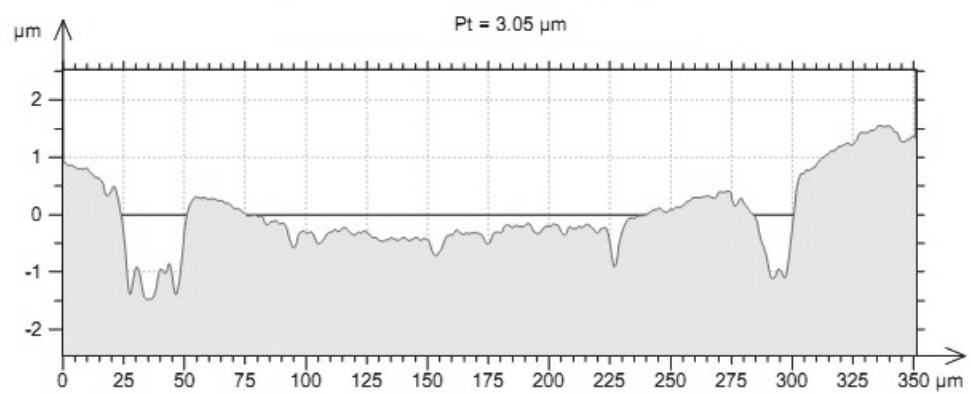

Fig. 6. Sample profiles of the coating surface on the contact fatigue test: a) plasma sprayed Ni-5\%Al coating after turning b) flame sprayed $\mathrm{Ni}-5 \% \mathrm{Al}-15 \% \mathrm{Al}_{2} \mathrm{O}_{3}$ coating on grinding, c) flame sprayed $\mathrm{Ni}-5 \% \mathrm{Al}_{-}-15 \% \mathrm{Al}_{2} \mathrm{O}_{3}$ coating on burnishing

Based on unfiltered 2D profiles were determined greatest depths of fatigue damage of investigated coatings. It is assumed that the maximum damage depth is represented by a $\mathrm{Pt}$ parameter specifying the total height of primary profile. For most samples the values of $\mathrm{Pt}$ parameter ranged from 3.4 to $5.81 \mu \mathrm{m}$. Often the average depth of fatigue damage was less than 1 $\mu \mathrm{m}$. This includes plasma sprayed Ni-5\% Al coatings, for which after burnishing and turning average damage depth was $0.5 \mu \mathrm{m}$. In the case of flame sprayed Ni-5\%Al coatings, on burnishing, the average depth of damage was $1.35 \mu \mathrm{m}$. Whereas thermally sprayed composite $\mathrm{Ni}-5 \% \mathrm{Al}-15 \% \mathrm{Al}_{2} \mathrm{O}_{3}$ coatings after burnishing treatment obtained an average depth of damage equal $2.1 \mu \mathrm{m}$.

In Tab. 1 the results of measurements of the surface area and volume of contact fatigue damage of alloy $\mathrm{Ni}-5 \% \mathrm{Al}$ and composite $\mathrm{Ni}-5 \% \mathrm{Al}-15 \% \mathrm{Al}_{2} \mathrm{O}_{3}$ coatings were presented. Based on the measurement results it was found that the plasma sprayed coating is characterized by higher resistance to fatigue failures of flame sprayed coating. This applies, for example burnished composite coatings. The flame sprayed $\mathrm{Ni}-5 \% \mathrm{Al}-15 \% \mathrm{Al}_{2} \mathrm{O}_{3}$ coatings showed a $64279 \mu \mathrm{m}^{3}$ volume of fatigue wear. Whereas plasma burnished composite coatings were characterized by volume loss of material equal $20377 \mathrm{~mm}^{3}$. Flame coatings, in which performed the $\mathrm{Al}_{2} \mathrm{O}_{3}$ reinforcing phase in an amount $15 \%$ volume fraction in matrix proved to be more resistant to fatigue then $\mathrm{Ni}-5 \% \mathrm{Al}$ coatings. Fatigue damages occurring in the Ni-5\% Al-15\% $\mathrm{Al}_{2} \mathrm{O}_{3}$ composite coatings in all cases had smaller surface area compared to the alloy coatings surface damages. The largest decrease of surface area of fatigue damage for plasma burnished composite coatings was observed. The surface area of the wear fatigue scar of composite coatings was 2.5 - fold lower than the alloy coatings. 
Influence finishing treatment on the fatigue wear of thermally sprayed coatings was observed. Grinded and burnished coatings had a similar resistance fatigue. The maximum difference is $5 \%$. Burnishing treatment promotes the growth of coatings resistance contact fatigue compared to turned coatings. The largest effect for the burnished composite coatings obtained by plasma spraying was found. After turning of coatings the surface area of the fatigue wear scar was 25847 $\mathrm{mm}^{2}$. After burnishing the surface area of the scar of fatigue wear was 2.7 times lower and amounted to $9459 \mathrm{~mm}^{2}$. Burnishing of plasma alloy coatings contributed to one and a half times reduce surface area of fatigue wear.

\section{Conclusions}

1. Plasma spraying coatings have several times a greater resistance to fatigue than coatings obtained by flame spraying.

2. Thermally sprayed $\mathrm{Ni}-5 \% \mathrm{Al}-15 \% \mathrm{Al}_{2} \mathrm{O}_{3}$ composite coatings are more resistant to contact fatigue, compared to the $\mathrm{Ni}-5 \% \mathrm{Al}$ alloy coatings.

3. Burnishing increases the contact fatigue resistance of thermally sprayed coatings as compared to the turning.

4. Thermally sprayed coatings after burnishing and grinding characterized by a similar of contact fatigue resistance.

\section{References}

[1] Burakowski, T., Wierzchoń, T., Inżynieria powierzchni metali, Wyd. WNT, Warszawa 1995.

[2] Charchalis, A. Starosta, R. Labuda, W., The analysis of finish tooling influence on contact fatigue of steel applied to sea water pump shafts, Journal of KONES Powertrain and Transport, Vol. 18, No. 2, pp. 85-92, 2011.

[3] Korzyński, M., Pacana, A., Cwanek J., Fatigue strength of chromium coated elements and possibility of its improvement with slide diamond burnishing, Surface and Coatings Technology, Vol. 203, pp. 1670-1676, 2009.

[4] Kukiełka, L., Bartosik, P., Szyc, M., Optymalizacja procesu kulowania strumieniowego ze względu na naprężenia wynikowe, Archiwum Technologii Maszyn i Automatyzacji, No. 30, pp. 117-125, 2010.

[5] Lee, S. D., Kim, T. W., Cho, Y. J., The effect of surface roughness on contact fatigue behavior using mesoscopic approach, Tribology Letters, Vol. 36, pp. 269-276, 2009.

[6] Olszak, W., Obróbka skrawaniem, Wyd. WNT, Warszawa 2008.

[7] Mhaede, M., Influence of surface treatments on surface layer properties, fatigue and corrosion fatigue performance of AA7075 T73, Materials and Design, Vol. 41, pp. 61-66, 2012.

[8] Patyk, R., Kukiełka, L., Projekt nowej metody sterowania rozkładem naprężeń własnych wprocesie wielokrotnego hybrydowego nagniatania gładkościowo-umacniajacego, Archiwum Technologii Maszyn i Automatyzacji, Vol. 30, pp. 143-150, 2010.

[9] Przybylski, W., Wiśniewska, A., Zastosowanie nagniatania w obróbce wykończeniowej części maszyn, Współczesne problemy w technologii obróbki przez nagniatanie, Vol 2, Wydawnictwo Politechniki Gdańskiej, Gdansk 2008.

[10] Przybylski, W., Zastosowanie obróbki nagniataniem w technologii siłowników hydraulicznych, Postępy Nauki i Techniki, No. 6, pp. 196 -201, 2011.

[11] Wyrzykowski, J. W., Pleszakow, E., Sieniawski, J., Odkształcenie i pękanie metali, Wydawnictwo WNT, Warszawa 1999. 
